\title{
Los cuerpos fantasmas y los muñecos rearmables de la modernidad: una lectura sociocrítica de Los perturbados entre lilas (1969), de Alejandra Pizarnik
}

\author{
Erick Palomo Romero ${ }^{1}$ \\ Universidad de Cartagena
}

\section{Resumen}

En este ensayo analizamos la única pieza teatral de la escritora argentina Alejandra Pizarnik, Los perturbados entre lilas (1969), y realizamos una lectura sociocrítica de la simbología que develan las imágenes del cuerpo fantasma y del cuerpo juguete del mecano. Estas imágenes del cuerpo son focalizadas debido a que consideramos que la lectura sobre el espesor oculto del cuerpo, y los valores que lo distinguen de otras manifestaciones corporales históricas, permiten identificar la visión profunda y crítica que sobre la realidad y el ser contemporáneo se plantea en toda la poética de la escritora argentina. El abordaje explicativo de la pieza se fundamenta en las teorías antropológicas y sociológicas sobre el cuerpo en la modernidad llevadas a cabo por David Le Breton (2002).

Palabras clave: imagen del cuerpo, cuerpo fantasma, autómata, juego del mecano, modernidad.

\begin{abstract}
In this paper we analyze the only theatrical work by the argentine female writer Alejandra Pizarnik, called Los perturbados entre lilas (1969), and we perform a criticism and social reading of symbolism to reveal images the game of meccano and phantom body. These body images are important point because we can do one reading about hidden thickness and the values of different historical manifestations of body and we can identify the critical and deep vision about contemporary man reality in the poetics of argentine female writer. The explanation on theatrical work has as base the anthropological and sociological theories about modernity body performed by David Le Breton (2002).
\end{abstract}

Key words: body image, phantom body, automaton, game of meccano, modernity.

\footnotetext{
${ }^{1}$ Profesional en Lingüística y Literatura de la Universidad de Cartagena. e-mail: palomoferii@hotmail.com
}

Recibido: Marzo, 2010 - Aprobado: Junio, 2010. 
[...] Una mano desata tinieblas, una mano arrastra la cabellera de una ahogada que no cesa de pasar por el espejo. Volver a la memoria del cuerpo, he de volver a mis huesos en duelo, he de comprender lo que dice mi voz.

Alejandra Pizarnik.

\subsection{La imagen del cuerpo fantasma y del cuerpo muñeco del mecano como representaciones del cuerpo moderno}

En 1972 Alejandra Pizarnik incluyó en la antología El deseo de la palabra un fragmento de Los perturbados entre lilas, con el título Los poseídos entre las lilas. No obstante, el texto completo, tal como hoy lo conocemos -y a pesar de estar firmado con fecha de 1969-, sólo se publicó en el 2002 bajo el sello de la editorial Lumen, en la reunión de su prosa completa. Estamos, pues, ante un texto relativamente reciente, si lo vemos desde la perspectiva de su publicación, pero más que reciente, "actual", si consideramos que las grandes obras literarias trascienden en el tiempo y se actualizan cada vez que encuentran un lector. Pues es el lector quien re-escribe el texto a partir del efecto estético que éste le proporciona (Iser, 1987). Consideramos, así mismo, que la lectura de la obra teatral de Alejandra Pizarnik devela, a partir de las imágenes del fantasma y del muñeco del mecano, una cara oculta: el rostro de la enajenación y los modos cómo ciertas pulsiones (desde adentro) anulan los edictos de nuestra civilización.

\subsection{El cuerpo fantasma ${ }^{2}$}

Los perturbados -como nos referiremos al texto de ahora en adelantees la única pieza teatral de Alejandra Pizarnik. Es una obra que discurre en un acto y en el trasegar de cuatro personajes: Segismunda, Carol, Macho y Futerina. Segismunda es el personaje que cuenta con

2 "Referirse al fantasma supone subrayar, primeramente, la obsesión y sobrevaloración de la imagen, lo tangible, la anulación de la visión dualista del hombre debido a la reducción del ser a lo corpóreo -una suerte de cosificación. Esta fisicidad prima lleva a la delineación de una colectividad corpórea impersonal, sin elementos marcadamente diferenciales de la esencia que puedan desmarcar al individuo. El resultado, una multiplicación de la réplica, un catálogo o cadena uniformada, en serie, en detrimento de la dimensión espiritual o aurática y, en confirmación ineludible de la caducidad de lo material, la difuminación y fragmentación de esta credencial sólo física merced a los discursos de la dispersión y la impersonalidad, tanto como la suplantación de la presencia real por medio de emersiones infográficas o pixeladas, producto de las nuevas tecnología" (Olivares, 2008). 
el poder de la palabra. Está montada y se desplaza en un "fabuloso" triciclo mecanoerótico y masca chicle con los ojos cerrados. Carol es un personaje que permanece al lado de Segismunda, mirándola atentamente, pero también "mirando al mundo a través de dos ventanas en forma de corazones" (2006: 165). Por su parte, Macho y Futerina evolucionan en un contexto erótico-escatológico y andan en triciclos destartalados. En cuanto a la "disposición del escenario teatral", las acotaciones iniciales nos muestran que estos personajes interactúan en una habitación infantil llena de objetos e imágenes sui géneris:

Una habitación con muebles infantiles de vivos colores. Luz como una agonía, como cenizas. Pero también, a veces, como una fiesta en un libro para niños. En la pared del fondo, cubierta de espejos, hay dos ventanas verdes en forma de corazones.

\begin{abstract}
A la derecha, en el proscenio, una puerta rosada. En la pared, junto a la puerta, un cuadro dando vuelta como un hombre orinando en un parque. En el proscenio, a la izquierda, dos pequeños féretrosinodoros, muy juntos, uno blanco a rayas verdes y el otro rojo con pequeñas flores de rafia (165).
\end{abstract}

Estas acotaciones no son, en realidad, instrucciones sobre cómo debe ser el escenario, o cómo deben actuar los personajes -objetivo de una acotación en las obras del teatro clásico-, sino más bien la descripción de un espacio y unos personajes irrepresentables. Esta estrategia nos permite identificar a Los perturbados entre lilas como una obra del teatro contemporáneo, y más específicamente, como una pieza del teatro del absurdo. Somos así introducidos en una habitación infantil adornada con imágenes de agonía y con objetos que chocan con lo infantil: "luz como cenizas", espejos que cubren la pared del fondo, el maniquí, la monja al lado de un payaso (agachados en un rincón) y "el caballito de cartón empenachado con arneses lujosos" (Ibíd.). Todos estos "objetos" marcan un contraste absoluto con la vitalidad que proyecta la imagen habitual del cuarto infantil.

Esta "luz como una agonía" puede ser, perfectamente, la imagen de una vela extinguiéndose, o la de una lámpara a punto de apagarse. Es angustioso, por lo demás, ver al maniquí con su estatismo que pasma, que contrasta definitivo con el movimiento y la energía vital del niño. Por otro lado, está la "luz como ceniza", símbolo de destrucción de lo que en un tiempo intentó alumbrar, pero que hoy no otorga sentido. Esta luz como ceniza es un índice sintomático de un mundo que ya no oculta su desintegración, reflejo a su vez del "desmoronamiento 
de las estructuras y los credos" (Lyotard, 1987: 22) y del estado fantasmal del hombre contemporáneo.

En esta habitación también están "los espejos del fondo", temibles. Ellos nos hacen recordar que, en la poética de Pizarnik, los espejos son siempre aterradores y simbolizan zonas prohibidas o espacios de negación: "en verdad tengo miedo a los espejos" (312), ha asegurado la autora en una entrevista. Los espejos están en Los perturbados para confrontar a los personajes con los monstruos de su propia identidad. Identidad dada en forma de una corporeidad a modo de objetos o de cosas que se mueven en un lugar sombrío donde la poca luz que queda agoniza y al mismo tiempo los hace agonizar. Así, los personajes se encuentran asociados a un registro nocturno, afirmación que podemos validar con el siguiente poema de Árbol de Diana (1962), en perfecta coherencia con el registro de Los perturbados):

\author{
cuando el palacio de la noche \\ encienda su hermosura \\ pulsaremos los espejos \\ hasta que nuestros rostros canten como ídolos
}

(2002: 99).

En esta habitación, que es el mundo, son los espejos -espejos de la disolución o laberintos sin retorno- los enclaves de "la ausencia, la soledad y la privación, los espacios en blanco invocados por Paul Auster" (Olivares, 2008). Así, los espejos, la luz como ceniza, el caballo de palo contaminado con arneses lujosos y todos los otros objetos que "adornan" esta habitación infantil, nos permiten develar un espacio que no es país para niños. Más bien, es un espacio para que sea habitado por "semas espectrales de la involución"(Ibíd.). De esta manera se configura la primera representación del cuerpo en Los perturbados: la del cuerpo fantasma. Pues interpretamos como "fantasmáticas" las delineaciones de estos personajes que nunca llegan a ser hombres o mujeres.

Esta habitación o casa, parecida a "una plaza de gran belleza metafísica" (169), como la denomina Segismunda, es el esbozo de un mundo en ruinas, un espacio sin lugar visto a través de los ojos del "niño fantasma", privado de su inocencia. Carol es el personaje con el que mejor se ilustra mejor esta idea del niño-fantasma: ve "al mundo a través de dos ventanas en forma de corazones" (165). Estas ventanas, que perfectamente pueden ser sus ojos, le permiten asomarse al mundo exterior y comenzar a describir en voz alta lo que 
existe afuera y relacionarlo con su propia existencia, y así hacerse consciente de su propia condición. A este respecto, es muy diciente la conversación que sostienen Carol y Segismunda:

SEG: Se abrió la flor de la distancia. Quiero que mires por la ventana y me digas lo que veas, gestos inconclusos, objetos ilusorios, formas fracasadas [...] Como si te hubieses preparado desde la infancia, acércate a la ventana.

CAR: Un café lleno de sillas vacías, iluminado hasta la exageración, la noche en forma de ausencia, el cielo como de una materia deteriorada, pasa alguien que no vi nunca, que no veré jamás [...]" (187).

Y ese "alguien” que Carol no ve nunca, y que no verá jamás (ese fantasma), es él mismo, sobre todo si sigue encerrado en medio de la "materia deteriorada". A su vez, esta "materia deteriorada" corresponde a la representación de un futuro, un crecimiento y un desarrollo que la sociedad y los sujetos mismos, con sus acciones, se han negado. Por ello, el texto presenta concordancia entre la desolación de los personajes y la gente vista desde la ventana; pero también, entre ellos y la desolación del paisaje. Así, Carol dice: "No encontré nada. [...] todo es horriblemente invisible" (188). En este micromundo todo está vacío y es invisible: el café con sus sillas, la noche y el cielo con sus formas de ausencia, transeúntes fantasmagóricos, espectros inexistentes en un letargo existencial. Una modorra perpetua que genera desconcierto y vértigo:

CAR: Una lámpara demasiado intensa, una puerta abierta, alguien fuma en la sombra, el tronco y el follaje de un árbol, un perro se arrastra, [...] (Repentinamente, en tono vengativo): Una equilibrista enana se echa al hombro una bolsa de huesos y avanza por el alambre con los ojos cerrados (193).

Definitivamente, esta representación fantasmal, planteada en enclave corporal, nos habla de seres envueltos en una deshumanización rotunda, aspecto que emparenta con algunos momentos del movimiento romántico, donde intelectuales, filósofos y artistas se rebelaron contra lo que percibían como una deshumanización propiciada por la industrialización, el crecimiento de las metrópolis y el anonimato de la sociedad de masas. Estos procesos serían el "viento violento que arrasó con todo (191)", para ponerlo en palabras de Segismunda, y que en Los perturbados se conecta magistralmente con la imagen del triciclo que irrumpe siempre de manera violenta en la escena. La imagen del triciclo es isotópica a lo largo de todo el texto: 
SEG: ¿Qué hiciste con tu triciclo?

CAR: Nunca he tenido triciclo.

SEG: Es imposible.

CAR: Y cómo lloré por tener uno. Me arrastré a tus pies. Me mandaste a la mierda.

Aparece un triciclo ruinoso cabalgado por Macho, quien viste andrajos pero lleva guantes colorados de esquiador (169).

En Los perturbados hay una relación entre la condición de los personajes fantasmas o personajes "cosas", con la imagen del triciclo que se anhela, pero del cual (al mismo tiempo) hay que deshacerse: "[...] tirá los triciclos y también de paso a estas cosas que pedalean” (174). Estos triciclos destartalados, rechinantes y precarios, son un claro cuestionamiento al mundo industrializado que hizo surgir sus máquinas y todo su andamiaje técnico para someter al sujeto moderno, o como bien lo ilustra el texto, para que el hombre esté montado siempre en él, convirtiéndole así en una prótesis más de la gran máquina. El triciclo, asumido aquí como estrategia textual de primer orden, nos permite afirmar que el mencionado cuestionamiento emerge, en el contexto referencial del mundo de la segunda mitad del siglo XX, en plena época post-moderna.

Los años sesenta marcaron una época de cambios y revoluciones: se dieron los más grandes y poderosos cambios de la cultura política y estética; se cuestionaron las estructuras del poder y las formas unívocas de ver el mundo y la ciencia occidental como única verdad; se gestaron movimientos de contracultura: los movimientos feministas, movimientos por los derechos civiles, los hippies del verano de San Francisco, los movimientos antinucleares, etc. Pero también es el momento en que asistimos a la "legalización ideológica de la hybris como signo específico" (Rodríguez Francia, 2009). Evidenciamos una consolidación de las ciencias médicas y biológicas como "incuestionables" ejes vectores del conocimiento sobre el hombre, después de que otras explicaciones perdieran su hegemonía o su fuerza y apareciera la era informática o las tecnologías de la información como relevos hegemónicos en el imaginario occidental.

En este sentido, la pieza teatral de Pizarnik comparte el ámbito de quienes, desde las postrimerías del siglo XIX, instaurarían en el arte la sospecha y la dispersión. Este es, indudablemente, su 
repertorio: la época científica por excelencia que, en nombre de la especialización, fracciona el mundo del hombre hasta el punto de hacerlo desaparecer en la sombra fantasmal. Es la época de la técnica que impulsa el progreso, irónica disposición de servicio para la humanidad, en detrimento de ésta. Ahora bien, el fantasma nunca es un ser humano. Es más bien la imagen etérea de éste, inmediata, si bien fugaz. Al no ser humano la imagen se convierte en icono de éste. Tal como ocurre con la fotografía, signo representativo o icónico del sujeto que representa, pero nunca el sujeto mismo. Este icono es índice de una realidad vacua, de la inestabilidad y desaparición, de ese "acaecer desencantado de lo que fuera realidad en su momento y ahora no es sino reverberación o simulacro, ese significado incompleto que resulta de la traducción de todo referente original" (Derrida \& Stiegler, 1998: 115).

El sujeto contemporáneo queda así instalado en "el descrédito o la dispersión, la privación de esencia y la anulación de los metarrelatos" (Lyotard, 1987: 22). Instauración de la pluralidad y el eclecticismo como formas de existencia. A este respecto, en su estudio sobre las imágenes de desencanto que contraen las nuevas tecnologías, Olivares señala:

[...] Hemos quedado reducidos a los píxeles fragmentarios de una instantánea sobre papel de periódico, a las proyecciones de nuestras hechuras corpóreas en una cámara web, a la imagen retocada o las entradas de diario de supervivencia en "blogs" -desesperados intentos por evitar la disolución del ser en el anonimato colectivo y el implacable paso del tiempo, fracciones de identidad suspendidas cual mercancía propia del neoliberalismo y dispersas en el seno de la hiperrealidad-, cuando no a la vacuidad de unas líneas que ocultan más que muestran sobre las ventanas del "chat", generalmente ligadas a esos "avatares" o "alter egos", constructos y contingencias a la carta que constituyen nuestras personalidades ad hoc en Internet y sus "metaversos" (2008).

En los perturbados los cuerpos fantasmas representan ilustraciones de este sujeto que abandona las delimitaciones y la asertividad individuales para diluirse en la impersonalidad colectiva.

\subsection{Muñecos: la imagen del juego de mecano}

Otra imagen que se configura en la pieza teatral es la de los "muñecos" que se pueden armar y rearmar al antojo. El texto muestra cómo Segismunda, personaje principal entre los cuatro, compró piezas 
para rearmarlos después de que éstos perdiesen sus extremidades en un accidente. Ella los rearma con "piezas nuevas", como bien lo afirma Macho, uno de estos personajes:

MACHO: ¿Querés saber la hora?

FUTERINA: ¿Para qué?

MACHO: Eso si que no sé. (Pausa.) Recordá cuando los tres camiones embistieron nuestros triciclos. Perdimos brazos y piernas. Segismunda nos compró brazos pero no quiso comprarnos piernas, solamente estos zancos ganchudos para empujar los pedales. (Ríen.) (172).

Aquí la pieza dramática pasa a configurar otra imagen del cuerpo: un cuerpo rearmado, a la manera del clásico juguete, con piezas a partir delas cuales pueden componerse diversas e ilimitadas construcciones o máquinas. Este famoso juguete, llamado popularmente juego del mecano, consiste en piezas metálicas de diversos tamaños, formas y colores, construidas con filas de agujeros para sujetarlas a otras piezas por medio de tornillos. Así, los cuatro personajes de Los perturbados son descritos como fantasmas, pero también como muñecos de construcción y reconstrucción: se les han añadido nuevos brazos y "zancos ganchudos". Tal representación nos conecta nuevamente con las tesis antropológicas de Le Bretón, cuando nos habla de la pérdida de organicidad del sujeto contemporáneo, plasmada en el modo como éste ha terminado usando y asumiendo su cuerpo. Afirma Le Breton que siempre que la técnica es capaz de sustituir lo orgánico, el cuerpo entra en la dinámica de lo re-producible:

Cada vez más la técnica es capaz de sustituir lo orgánico, incrementar el rendimiento del cuerpo y darle parcialmente la razón a la filosofía mecaniscista representada por Descartes y la medicina de su tiempo. Para contener las deficiencias originadas en la enfermedad, en los accidentes, en la vejez, los cirujanos disponen, hoy, de un asombroso repertorio de prótesis (aparato artificial que reemplaza un órgano o una función orgánica) y de ortesis (que refuerzan un órgano o una función lesionada). Bioquímicos e inmunólogos trabajan en conjunto para crear sustancias biocompatibles. La fábrica del cuerpo humano entra en la era de la reproducción industrial (2002a: 219).

En concordancia con esto, podemos afirmar categóricamente que los personajes de Los perturbados son encarnaciones de la fractura de la 
unidad humanay del vacío axiológico que alcanzó al cuerpo occidental por vía de la medicina moderna. Este vacío de sentidos en medio de una sociedad cada vez más secular ha configurado la resultante lógica de una concepción mecanicista del individuo, encarnada en los usos de su propio cuerpo, en la concepción de su funcionamiento y de su realidad: el cuerpo es reducido a un rompecabezas o, como afirma Le Breton, a "una versión complicada del juego del mecano" (227).

Paradógico, si recordamos que uno de los propósitos de la razón cartesiana, y del desarrollo de la ciencia occidental a partir de la modernidad, era proporcionar al sujeto la individuación, otorgándole un rostro y una identidad. No obstante, el predominio del positivismo científico, que ayudó a delinear la visión del cuerpo enmarcado en las ciencias biomédicas (al erigirse como eje vector de las lecturas hegemónicas del sujeto occidental), dio al los seres humanos la conciencia de que poeseían un cuerpo, implicando la consideración de que éste era sólo un triste eco del espíritu. Ello restaría a la axiología del cuerpo su anterior capacidad de configurar lo humano mismo y permitirle fluir en la "red cósmica de relaciones", vinculándolo "con todas las energías visibles e invisibles que recorren el mundo" (Le Breton, 2002a: 228).

Cuando se define al cuerpo de este modo, ocurre la pérdida de la carne, convirtiéndose el cuerpo, bajo el modelo mecanicista, en algo plano -no a la manera de las representaciones del Medioevo, donde el cuerpo se llenaba con la configuración de sentido de la corporeidad mística de la Iglesia, sino en una textura lisa, sin marcas de sentido que lo configuren en un momento donde los "valores" de la modernidad no lo interpelan-. Esto hizo que, pieza por pieza, el ser humano se fuese despedazando, dislocando, "disociándose en el alfabeto de las posibilidades combinatorias (fuerzas, palancas, filtros, bombas, circuitos, corrientes, procesos, etc.)" (Le Breton, 2002a: 228). Una composición de piezas parciales, de fantasmas definidos y circunscritos por medio de un "corte funcionalista y estructurable. Así es el cuerpo operacional" (Guillon, citado por Le Breton, 2002a: 246).

Encontramos pues, con la imagen del muñeco rearmable de Los perturbados, una proyección ontológica creada por la nueva realidad de inicios de la cirugía médica, pero hegemonizada en las últimas décadas con los avances y descubrimientos de la trasplantación. Es una imagen que nos permite una lectura hacia arriba y hacia abajo en el campo de representaciones que el cuerpo enmarca. Hacia abajo, pues las sofisticadas cirugías que "modifican" al ser humano (a través 
de los nuevos usos dados a su cuerpo) permiten dibujarle como "la versión mejorada del juguete del mecano" (Le Breton, 2002a: 227), con elementos disponibles y permutables, en su mayoría materiales técnicos. Y hacia arriba, porque el cuerpo representado configura un sin sinsentido y simboliza el creciente proceso de mecanonización ${ }^{3}$ de la medicina moderna. El avance de las cirugías y de la ortopedia nos permite en la actualidad encontrar prótesis para todas las extremidades: con todas estas nuevas piezas el ser humano es rearmando en medio de un circuito de producción y funcionalidad. Al respecto, es muy puntual Guillon, citado por Le Breton:

\begin{abstract}
El hombre con una prótesis, es siempre una demostración: la prótesis pertenece al orden del rendimiento [...] el hombre con una prótesis, cualquiera que sea, está condenado a una verificación de ostentación; mostrar y demostrarse que él (el hombre) y ella (la prótesis) funcionan. [...] El hombre asistido experimenta, de este modo, menos su relación con el mundo de lo que verifica, espectacularmente, su propia funcionalidad. La simulación mecánica del cuerpo no protege al hombre con una prótesis de la angustia por ser un híbrido (2002a: 220).
\end{abstract}

Vemos, pues, que la medicina de nuestro tiempo se encuentra fundada en una antropología residual: lejos de ser un saber sobre el hombre, se ha convertido en un saber anatómico y fisiológico en estado refinado. Esto se ha dado, principalmente, por la excesiva fragmentación a la que ha sido sometido el cuerpo con la hiperespecialización de la medicina actual en torno a ciertas funciones y órganos, la utilización de nuevas tecnologías de diagnósticos por imágenes y el recurso terapéutico cada vez más dependiente de la técnica. El cuerpo, ciertamente, ya estaba diferenciado del hombre desde las lecturas platónicas y cartesianas, pero en la actualidad se encuentra fraccionado al extremo, visto en la extensión de sus piezas.

\title{
1.3.1. El autómata: la versión complicada del juguete del me- cano
}

Esta versión complicada del juguete del mecano se da precisamente por el carácter híbrido de ser humano (mitad hombre/mujer-mitad máquina). Una suerte de autómata de umbral:

\footnotetext{
${ }^{3}$ Acuñamos este término para describir el auge de procedimientos quirúrgicos de trasplantación de órganos, el auge de las cirugías estéticas y reconstructivas y de todo el andamiaje técnico que se ha construido en el campo médico; pero también para describir los resultados sicológicos y sociales que estos procesos han acarreado.
} 
Car da vueltas por la habitación. Por el modo de caminar o por lo que fuere, parece un autómata o un muñeco; no un ser viviente. Rumores de lluvia (192).

Car, el muñeco, parece ahora un autómata. Da vueltas sin sentido en medio de la habitación, y su relación con el entorno ha cambiado. Ahora todo se torna para Car monótono, en perpetua circularidad, en un incesante circuito cerrado. Podemos atribuir este cambio al hecho de que Car ha sido alterado y rearmado, tal como se puede hacer con una máquina. Por eso no parece un ser viviente; su relación con el mundo ha sido modificada. El cuerpo es, ciertamente -como lo ha estudiado la fenomenología y la antropología- condición de la mujer y el hombre, el lugar de su identidad: lo que se le quita o agrega modifica la relación que mantiene con el mundo (Cf Le Breton, 2002a: 248). Cabe recordar aquí, sin embargo, que Carol llora por ser parte de eso que hemos llamado la "gran máquina del mundo técnico", y por lo tanto es como si él mismo hubiese deseado ser una máquina: "Y cómo lloré por tener uno [un triciclo]. Me arrastré a tus pies. Me mandaste a la mierda" (190).

Esta actitud de Carol ilustra muy bien la ambigüedad del sujeto contemporáneo, quien siente la desazón producida por la pérdida axiológica en la modernidad, pero al mismo tiempo "disfruta" del hedonismo planteado por el gran triciclo que ella ofrece. Es decir, el mismo sujeto moderno proclama a voces la fascinación por la gran maquinaria, tanto que desea convertirse en su prótesis, anclarse a ella y pedalearla todo el tiempo, sin importar que con ello empeñe su libertad. El llanto de Carol simboliza la fascinación por el mundo industrial y sus "gadgets". Es índice de la obstinación humana por el diseño de máquinas que remplacen a los sujetos en la realización de sus antiguos trabajos, y por la construcción de artificios que puedan imitar la mayoría de sus funciones.

Este obsesivo maquinismo, sin embargo -trazado inicialmente como medio de liberación de las tareas cotidianas y del trabajo artesanal (con la finalidad de dar mayor tiempo a actividades del "espíritu", como el arte y la filosofía)-, termina convirtiendo al ser humano en un muñeco que "depende de la marcha del segundero" (Sábato, 1951: 35), en un engranaje más del gran triciclo, en un autómata que da vueltas y vueltas en una habitación. En Los perturbados podemos ver así cómo se configura una imagen clara de la significación de la técnica para una cultura completamente determinada por su accionar y que entabla una relación entre el hombre y la máquina mediada por el poder cada vez mayor que ésta ejerce sobre aquél. La constante presencia de máquinas que invaden cada vez su espacio vital han 
terminado proyectando al ser humano una especie de "imagen pantalla" de sí mismo y con ello dispensándolo de "preocuparse por su propia contingencia, por su individualidad" y "finalmente por su libertad", al otorgarle una "falsa autonomía" (Beaune, 1990: 449):

\begin{abstract}
Esnecesarioaquírecordaralgunos excesos deunaorganización industrial y fabril, inhumana a fuerza de racionalidad y que solo deja al individuo pobres alternativas: se advierte en este caso, que la automatización se ha convertido en una noción social y ante todo económica -la dimensión técnica no es más que un medio del que el hombre no es más que una pieza menor (Beaune, 1990: 448).
\end{abstract}

Esta obsesión por crear máquinas que lo imiten, esta imagen pantalla que la gran organización industrial ha creado y la reducción a pieza a la cual es sometido, han acabado haciéndole creer al ser humano que él mismo es la máquina superior. De ahí la fantasía subyacente en las investigaciones modernas de la ciencia: la de lograr un cuerpo que, como una máquina, no envejezca, y principalmente, que no muera. Desde la ciencia se modela afanosamente un cuerpo donde todos los órganos puedan ser modificados o reemplazados cuando se gasten, cambiados por otros de mayor rendimiento y así, como un reloj, "marcar el tiempo pero no estar afectado por él". Es "el hombre biónico o el cyborg del cine" el que se anuncia en el horizonte de un futuro no muy lejano. Ese resto humano que será "realzado por prótesis, por estimuladores, por pilas, por microprocesadores" (Olivares, 2008), que sustituirán las funciones fisiológicas, los órganos envejecidos o los que no funcionen bien.

Es evidente que para las orientaciones técnicas y científicas actuales el cuerpo es un trazo no definitivo, no perfeccionado, cuyos rendimientos deben ser controlados y mejorados. Por ello uno de los ideales modernos es el del cuerpo siempre joven y bello que aparece en la televisión y nos bombardea desde las revistas de salud y moda. Pues este cuerpo reafirma "los valores centrales modernos: la juventud, la seducción, la vitalidad y el trabajo" (Le Breton, 2002a: 142). Mientras que el cuerpo del anciano, en palabras de Le Breton, "encarna lo reprimido", y hace recordar, a manera de latiguillo descorazonador, la precariedad y fragilidad de la condición humana. Y, de manera agobiante, la "incapacidad del hombre moderno para saber simbolizar el hecho de envejecer" (2002a: 142). El ideal entonces, para el entramado moderno, sería hacer desaparecer totalmente ese cuerpo envejecido, ya que es un estigma intolerable que remite, entre otras, a la idea del cuerpo desechable, no útil. Erving Goffman da, 
al respecto, una definición muy diciente sobre el cuerpo estigmatizado que incluye tanto al discapacitado como al anciano:

Un individuo que habría podido con facilidad ser admitido en el círculo de las relaciones sociales ordinarias, posee una característica tal que puede llamarnos la atención y esto hace que nos alejemos de él, destruyendo, de ese modo, los derechos que tiene respecto de nosotros de acuerdo con sus otros atributos (1975: 17).

Desde esa mirada sospechosa, suprimimos el cuerpo viejo: el que se necesita es el cuerpo de los gimnasios, de las revistas de belleza, el cuerpo vegetariano, el cuerpo light, el cuerpo completo, capacitado, el cuerpo amoldado al canon de belleza desde procesos de mecanonización. Esta idea moderna de eliminar el cuerpo envejecido se encuentra irónica y magistralmente ilustrada en Los perturbados, con la peculiar ópera de Segismunda. Vemos a Carol recordándole a Segismunda una pieza de 18 actos que dura tres minutos, donde ella pone a bailar, ataviados con tutús celestes y zapatillas rojas, a un grupo de 35 ancianos sobre 35 triciclos. A continuación, se detiene el diálogo entre Carol y Segismunda, y aparecen los ancianos en una especie de acotación ambigua que permite configurar una escena "clásica" de lo que se denomina teatro dentro del teatro, pero que al mismo tiempo es una escena surreal debido a que los actores no son los personajes, sino más bien unos "viejos" salidos de la imaginación de Segismunda y que irrumpen pedaleando en la escena, para finalmente desvanecerse:

(Las luces se desvanecen; Seg y Car también. Luz fantasma, poética. Se escucha "El lago de los cisnes" (o algo parecido a la máxima velocidad). Irrumpen, pedaleando, los 35 ancianos del apocalipsis de Segismunda. De repente: imprevisto silencio seguido por una súbita oscuridad acompañada de un fuertísimo estampido. Un reloj tictaquea ruidosamente; se escuchan jadeos como si una muchedumbre fornicara o agonizara. Al encenderse las luces, Seg y Car aparecen en el mismo lugar y en la misma postura, pero como si en el lapso de la representación de la ópera hubiese estallado una bomba. La casa -"la plaza metafísica"- ha quedado en ruinas.

Pausa. Largo silencio (178).

Son estos cuerpos ancianos que danzan a diario por las calles de la habitación-mundo, estos moradores molestos de nuestra mirada, a los que la gran maquinaria quisiera desaparecer. En Los perturbados 
ellos también son seres fantasmales, pero además, caricaturizados por la doble mirada que permite el teatro dentro del teatro, y que los lleva al paroxismo espectral. Cuerpos sin peso, arrojados, con la explosión de la bomba (más allá de su mundo extraño y desfigurado), a la insustancialidad. No obstante, son contagiados también por la mirada, por ese "llamarnos la atención", como lo indica Goffman, que los destruye en un parpadeo de disolución. Cada pedaleo de los triciclos destartalados es el umbral de paso de lo real a la dimensión más insustancial del fantasma. Asolados ya por esa coreografía surrealista, los fantasmas ancianos sienten la llamada del abismo para finalmente ser deglutidos finalmente por la explosión de la plaza metafísica, el drama de la finitud humana.

\subsection{El drama de la finitud}

El hombre es un ser frágil, falible, que puede equivocarse porque no coincide consigo mismo, porque es simultáneamente más grande y más pequeño que sí (Cf. Ricoeur, 2004). ¿Dónde encontramos esta desproporción? Es aquí donde se plantea la paradoja de nuestros héroes. Los personajes de Los perturbados están claramente marcados por una desproporción, por una conciencia de su paradoja actual: la de reconocerse sustancial y necesariamente finitos, a pesar de las promesas de la ciencia. En cualquier caso, lo que el drama quiere poner de relieve es que la condición fantasmal, resultante de la fascinación, no es nuestra realidad original, no constituye nuestro estado ontológico primero.

Cabe la posibilidad, sin embargo, de interpretar los dos estados -el de la fascinación y el de desencanto- no de forma sucesiva, sino superpuestos. El drama manifiesta el estado "posterior" de fascinación en un contraste con el estado "anterior", cuando aún no se habían erigidos los "dioses" de la modernidad y se convivía con otras formas de asumir lo corporal. Es justamente así como la pieza alcanza su profundidad, al dramatizar la fascinación como un suceso surgido en la modernidad y que convierte al individuo en una especie de narciso moderno. A partir de ese momento, el resultado de la fascinación anima el movimiento de la civilización, y el apetito de posesión, de "belleza", de poder, de conocimiento e de individualidad parece constituir la realidad humana. Esta escisión del ser humano consigo mismo se presenta de forma ya brutal y definitiva en el caso de Los perturbados, enfrentada al mismo tiempo con un desencanto expreso de los personajes por los resultados de dicha fascinación.

Podemos resaltar lo anterior cuando Segismunda, creadora de la ópera, luego de la explosión -y al ver la "plaza metafísica" en 
ruinas- pregunta en tono airado: “QQuién habrá sido el bastardo de fantasmas sifilíticos?" (179). Pregunta que distancia a Segismunda del acto destructivo de los 35 personajes que son símbolos del umbral antropológico del ciclo vital (la vejez), y nos permite inferir que Segismunda, al igual que Carol y los otros dos personajes, gravita entre la alienación y el descontento, convirtiéndose con ello en un "héroe complejo" por medio del proceso dramático de contradicción al que son sometidos ${ }^{4}$. El "héroe complejo" no espera que la sociedad le salve o redima, sino que, más bien, él mismo, si es posible, se salva. Es decir, a través de su acción, podría llegar a salvarse de su propia degradación.

Los personajes de Los perturbados se saben, efectivamente, espectros fantasmales o muñecos de mecanos, y por lo mismo manifiestan un expreso deseo de querer huir de la condición que los perturba. Veamos, al respecto, cómo Carol evidencia su autoconciencia y desencanto: "Me voy porque la vida que llevo aquí, mi vida, no me gusta" (178). O las dicientes palabras de Segismunda, consciente de que, como un muñeco, se ha ido desmoronando pieza por pieza, hasta perder sus contornos antropológicos originales, convirtiéndose en un fantasma:

[...] Y ahora, ¿qué hacemos aquí? Indefinidos, desposeídos, imbéciles. Nos desmoronamos en forma anodina. Nuestra condición es tan funesta que ni siquiera puede haber duelo (184).

Segismunda siente que no existe y busca, en medio de su residuo corporal, lo que queda de ella, lo que vive en su lugar, y aunque no lo logra definir de manera total, sí sabe que la desintegración procede del viento que todo lo ha arrasado. Es decir, reconoce que es una fuerza exterior la que le ha causado dicha condición traducida en enclave de desencanto:

[...] Yo ya no existo y lo sé; lo que no sé es qué vive en lugar mío. [...] Un viento violento arrasó con todo. Y no haber sabido hablar por todos aquellos que olvidaron el canto [...] (191).

\footnotetext{
${ }^{4}$ Utilizamos el término "héroe complejo" en el sentido que lo vierte Alfonso Sastre: "Es decir, en la tragedia compleja, reaparecen, modificados, los efectos 'clásicos' de la tragedia, transcendidos en una catarsis-que-es-ya-toma-de-conciencia; operación en la cual se produce articuladamente, dialécticamente, el doble movimiento distanciación (intencional = toma de conciencia)-reconocimiento (identificación = momento catártico). (0 viceversa: reconocimiento-distanciación)" (Sastre, citado por Stanfield, 1986: 327).
} 
Ella es un ser en crisis, caracterizada principalmente por su incapacidad para abordar una existencia así planteada. Siente que algo se perdió en el camino de su evolución antropológica y social, que quedó desposeída de los símbolos que la configuraban y que, como consecuencia del sin sentido traído por un viento arrasador, ahora está desnuda, hecha girones. Tal autoconciencia profunda de Segismunda nos explica por qué sale vestida con unos atuendos peculiares. Las acotaciones la describen minuciosamente a partir de su atuendo: pasa a cubrir entonces su desnudez y sale vestida con una gran cantidad de trapos.

[...] capa gris modelo Lord Byron o George Sand [...], pantalones de terciopelo rojo vivo modelo Keats, una camisa lila estilo Shelley, un cinturón anaranjado incandescente modelo Maiakovski y botas de gamuza celeste forradas en piel rosada modelo Rimbaud. De su cuello pende un falo de oro en miniatura que es un silbato de roca rala y toda su persona evoca el otoño (166).

Podemos leer en estas acotaciones una humor irónico, o más exactamente, paródico, entendiendo como parodia la "imitación consciente de un texto, de un personaje o de un motivo" (Fabb, 1989). Son traídos a colación nombres de distintos escritores, como los modelos primigenios a parodiar, pero se los toma no para poner de manifiesto un distanciamiento y realizar una crítica a dichos modelos, sino más bien como una especie de mezcla discursiva donde la voz acotadora se apropia de la imagen del personaje de forma caricaturesca para darnos un retrato irónico de él. En el caso de Segismunda, la ironía que se proyecta en lo peculiar de su atuendo enfatiza la tensión libertad-opresión del mundo contemporáneo. De hecho, la alusión a escritores simbolistas o románticos, marcados todos por una vida de excesos según la moral de la época, es clave para detectar lo que hemos expresado.

Lord Byron, por ejemplo, consiguió la reputación de excéntrico: era famoso por su vestimenta extravagante y colorida, por sus relaciones románticas con hombres y mujeres. Por otro lado, Georges Sand, cuyo nombre real era Aurore, se hizo famosa porque, luego de abandonar a su esposo, comenzó a preferir el uso de vestimentas masculinas, y alternaba esta práctica con el hecho de presentarse con prendas femeninas en reuniones causando cierta incomodidad y confusión en algunos círculos sociales, especialmente, dentro de la aristocracia de la época. Georges Sand utilizaba su ropa masculina como un "disfraz" que le permitió circular más libremente por París, obteniendo acceso a lugares que de otra manera hubieran sido negados para una mujer de su condición social. 
Así, pues, la alusión es clara cuando Segismunda sale vestida con una capa modelo Lord Byron o Geoge Sand. No se nos define simplemente la estética superficial del personaje, más bien se construye con ello una ambigüedad íntimamente ligada tanto a los presupuestos románticos como simbolistas: la ambigüedad y el hermetismo como el carácter más íntimo del símbolo y, por tanto, como su mayor fuerza expresiva. Segismunda persigue esos símbolos, los busca con anhelo en el lenguaje, en la poesía, pero también en lo prohibido. A través del vestuario de Segismunda, podemos encontrar la presencia de la carga angustiosa-desesperada-trágica de autores románticos y simbolistas que aparecen como el recuerdo constante del dolor que ella guarda. Multiplicada y estoica, Segismunda resiste: continúa buscando, hasta el agotamiento, los signos y el símbolo que le den sentido a su existencia. Pues, aunque pedalea en su triciclo, sabe que es un muñeco mecanonizado. En otras palabras, que está muerta, pero que al mismo tiempo sufre por esa condición:

SEGISMUNDA: (extrae un cigarro del bolsillo de su camisa y lo enciende cuidadosamente) Es verdad que renuncié hace mucho a ser una persona. No obstante, vivo. ¿Por qué? No lo sé. Pero es así y sufro. ¿Acaso no he andado en busca de esos signos hasta el agotamiento y no he mirado hasta casi volverme ciega? (175).

\subsection{Primer plano trasfondo}

La modernidad suministró la razón cartesiana y el imaginario burgués como condiciones sine quan non para asumir y explicar el mundo. Pero ha sido suficientemente claro que las explicaciones del mundo desde estas ópticas no abarcaron toda la realidad compleja del ser humano, debido a que delinearon a un sujeto fantasmal, sin carne. El cuerpo-máquina de la modernidad está sometido al rigor burgués del buen decir y del buen hacer, a diferencia del cuerpo-grotesco "del júbilo carnavalesco que es un cuerpo que no es separado y que ensambla a los hombres entre sí [...] signo de alianza" (Le Breton, 2002a: 31).

Para Le Breton, en el cuerpo de la sociedad medieval (el de las tradiciones del carnaval) no se distingue al hombre y a la mujer como un factor de individuación, tal como sucederá con el cuerpo de la modernidad. En esta tradición no hay una ruptura entre el ser humano y su cuerpo, pero la retirada progresiva de la risa y de las tradiciones de la plaza pública marcará la llegada del cuerpo moderno como instancia separada, como distinción entre un cuerpo y otro. Afirma Le Breton que el cuerpo grotesco no es plano, como sí 
lo es el moderno, pues está formado por salientes, protuberancias, desborda devitalidady se entremezcla con la multitud, presentándose insatisfecho con los límites que permanentemente trasgrede:

El cuerpo grotesco, [...] se excede a sí mismo, atraviesa sus propios límites. El acento está puesta en las partes de su cuerpo en que éste está, o bien abierto al mundo exterior, o bien en el mundo, es decir, en los orificios, en las protuberancias, en todas las ramificaciones y excrecencias: bocas abiertas, órganos genitales, senos, falos, vientres, narices (Bajtín, citado por Le Breton, 2002a: 31).

Esta cita es clave para entender lo que se plantea como respuesta actualizada en Los perturbados. Pues las alusiones a lo erótico, el lenguaje de lo obsceno y lo escatológico, en medio de imágenes de negación e imposibilidad, configuran un humor irónico que nos permite entrever cómo la modernidad ha despreciado los órganos y las funciones carnavalescas para convertirlas en objetos de pudor. Observemos, por ejemplo, cómo se concrea en Los perturbados la imposibilidad del roce de los cuerpos. El texto nos muestra que hay una imposibilidad para el contacto físico: "Las cabezas se acercan dificultosamente. No llegan a rozarse. Se apartan" (178). Ello se actualiza, así mismo, con imágenes que combinan lo escatológico y lo obsceno, en contrapunto con las que denotan opresión: así aparecen triciclos mecanoeróticos destartalados y rechinantes y un cinturón de castidad enfrentados a la imagen de un hombre orinando en un parque, a Macho que eructa con devoción en medio de la escena, al chino que Segismunda manda a la mierda y que, antes de desaparecer, vomita sobre los pies de Carol.

El triciclo, símbolo de la gran máquina moderna, se instaló para otorgar placer al sujeto moderno. El goce de los artilugios de la modernidad y su aparataje técnico pasó de manera arbitraria a remplazar la libertad del manejo de los órganos y el goce sexual desde lo público, que se podía verificar en las sociedades medievales y con tradición del carnaval, por un goce atrofiado desde lo privado (y oculto), transversalizado por las nuevas formas de interacción permitidas por los medios masivos de comunicación y, muy especialmente, la Internet. Así, la pieza actualiza, más allá de las prohibiciones burguesas y los manuales del "buen" comportamiento, las manifestaciones libertarias de la corporeidad del carnaval, subrayando que éstas no se emparentan con los triciclos: "No podemos con los triciclos en las entrepiernas" (181).Y además, lo hace con la expresión de la nostalgia de un pasado donde el placer no estaba negado: 
FUTERINA: ¡Ah, ayer era el canto de una guitarra en un albergue lejano, era el horizonte salvaje en un dormitorio con trapecios y hamacas para ejecutar ciertas posiciones que [...] aquí están prohibidas. [...] No me evoques buenos recuerdos (172).

O desde la ambiguedad:

MACHO: ¿Me deseás?

FUTERINA: Sí, ¿y vos?

MACHO: También. A pesar de todo, se para bien (172).

Pero de manera contundente, reafirma la libertad córporea con la definición que Segismunda da al término obscenidad:

SEG: La obscenidad no existe. Existe la herida. El hombre presenta en sí mismo una herida que desgarra todo lo que en él vive, y que tal vez, o seguramente, le causó la misma vida (168).

Con esta definición de lo obsceno, el resultado del ocultamiento moderno del goce se convertiría en una especie de "apoyo", un sistema de apuntalamiento a partir del cual Segismunda construye o re-construye su interacción con la realidad. Lo obsceno, es decir, lo que no se puede mostrar, no es más que una construcción realizada por la regulación de la moral moderna que tiene su enclave en la ética burguesa de tradición judeo-cristina y que, por tanto, no es connatural al cuerpo. La definición de Segismunda desacraliza la respuesta del imaginario burgués y trae a primer plano la visión de los sectores populares donde la persona está vinculada a una totalidad cósmica que la supera, esa donde las fronteras de la carne no marcan los límites de la "mónada individual". Pues es "un tejido de correspondencia que entremezcla en un destino" a todos los seres de la naturaleza e incluso lo invisible, y en este tejido de correspondencia todo significa, pues todo está indisolublemente vinculado entre sí (Le Breton, 2002a: 35).

De modo que la respuesta que se actualiza en la relación primer plano-trasfondo es la que retorna al cuerpo humano su categoría de vector de una inclusión para que deje de ser el motivo de una exclusión. En Los perturbados se alcanza a ver la imagen del cuerpo que vincula al hombre con todas las energías visibles e invisibles que recorren el mundo, replegada por la del modelo anatómico, por la de los códigos del saber-vivir o los modelos mecanicistas. En este límite del sistema de sentido el texto se instaura y nos devuelve la imagen 
del cuerpo interconectado con el cosmos ${ }^{5}$. Por otro lado, este cuerpo no quiere ser eterno y petrificarse como el cuerpo moderno, sino que prefiere participar regularmente de la ceremonia vital del renacer: "Preñado de una vida que habrá de nacer o de una vida que habrá de perderse, para volver a renacer" (Le Breton, 2002a: 125). Sería esta la segunda respuesta que se actualiza en Los perturbados: la que plantea estratégicamente la relación muerte-vida y vida-muerte como diálogo del fluido vital del cuerpo conectado con el cosmos. La imagen de la muerte irrumpe en la poética de Pizarnik más inclinada a un juego del significante, pero siempre con la desintegración de la subjetividad como fondo. De igual forma, aparece en el esquema dramático inclinada a solucionar lo que ha sido la desintegración del sujeto apartado de su axiología cósmica.

La muerte, que es uno de los innombrables de la modernidad, es actualizada por el texto dramático como la salida definitiva del caos moderno. Cuando Carol nos dice que se va, porque la vida que lleva allí no le gusta, propone la ida total de la casa. Es decir, la muerte definitiva como salida. A este respecto, cabe recordar que el "héroe complejo" no espera la redención por parte de la sociedad. De ahí el elogio que Segismunda hace de la muerte, al compararla con el sueño:

SEG (con mucho cansancio): No me dejan dormir. Cállense o hablen más bajo. Si pudiera dormir un minuto, un año. Si durmiera, detrás de mis ojos de dormida yo vería los mares y los laberintos y los arcoíris y las melodías y los deseos y el vuelo y la caída y los espacios de los sueños de los demás vivientes. Yo podría ver y oír sus sueños (185)

La muerte, para Segismunda, sería el descanso del peso agobiante que impone la modernidad: le permitiría, como en un sueño, acercarse a las melodías de los sentidos de la existencia. Ella reconoce que la muerte trae la liberación de su condición de fantasma y de la mecanonización que el mundo le ha impuesto. Sabe que el no morir sería una esclavitud aburridora y agobiante. De allí que cuando pelee con Macho y Futerina les grite, a modo de maldición: “iMalditos! ¡Que no se mueran nunca! ¡Que sólo sueñen con caballos tuertos!”

\footnotetext{
5 "Recordemos, a propósito de Freud, que el deseo no es búsqueda de un objeto o de una persona que aportaría satisfacción. Mejor dicho, es más que eso. Es la búsqueda de un lugar, de un momento de felicidad sin límite, de un paraíso perdido" (Corrales, 2007).
} 
(175). Buscar esa muerte implica la valoración del suicidio como mecanismo de encuentro:

CAR: Juguemos entonces al paciente y el médico

SEG: ¿Y si nos aburriéramos?

CAR: Nos suicidásemos

Drama perturbador, pero en apertura hacia la esperanza de la muerte como liberadora del tedio axiológico propiciado por la modernidad. En él se da una salida que va en contravía con la obsesión de la ciencia moderna por despojar al hombre de su mortalidad. Para "los perturbados", la inmortalidad -y más aún en la modernidad- sería un maldecir al hombre, sumirlo en la postración total, sobre todo porque es en la otra orilla (la de la muerte) donde se puede ver lo que hay en el jardín de lo prohibido. A propósito de este "jardín”, en una entrevista con Martha Isabel Moia, realizada en 1972, la autora respondió:

M.I.M.: ¿Entraste alguna vez en el jardín?

A. P.: Proust, al analizar los deseos, dice que los deseos no quieren analizarse sino satisfacerse, esto es: no quiero hablar del jardín, quiero verlo. Claro es que lo que digo no deja de ser pueril, pues en esta vida nunca hacemos lo que queremos. Lo cual es un motivo más para querer ver el jardín, aún si es imposible, sobre todo si es imposible (312).

Posibilidad permitida por el goce de la sexualidad sin tapujos y por la muerte. Es por ello que el accionar de "los perturbados" nos invita a pensar que aún puede haber una salida entre tantas opciones que brinda la misma modernidad, y quizá, desde toda muerte, es posible suponer que en el fondo puedan hallarse los orígenes, entendiendo el devenir humano y su expresividad en orden dramático. La sexualidad y el amor primigenio y la muerte serían entonces esos eternos silencios que la voz lírica de los poemas de Pizarnik clama a gritos: silencios que nos sacan del murmullo de un mundo donde reina la máquina. Son estas, tal vez, las respuestas que se actualizan como primer plano en el contexto de un mundo moderno.

\section{Bibliografía}

Álvarez, J. \& Pita, J. M. (1994). Historia general del Arte. Madrid: Ediciones del Prado, vol. I.

Bajtín, M. (1987). La cultura popular en la Edad Media y el Renacimiento. El contexto de François Rabelais. Madrid: Alianza. 
Beaune, J.C. (1990). “Impresiones sobre el automatismo clásico (siglos XVIXIX)”. En Feher, M et.al. (Eds). Fragmentos para una historia del cuerpo humano. Madrid: Taurus, vol. I, pp. 447-498.

Corrales, A. (2007). "El cuerpo en la literatura o la literatura del cuerpo" (Ponencia leída el 27 de noviembre del 2007 en el "Conversatorio sobre Literatura y Corporalidad" convocado por el Colectivo de Artistas Costarricenses en el marco de su proyecto escultórico "El jardín de las delicias", en la Galería Génesis de San José, Costa Rica.

Deleuze, G. \& Guattari, F. (1997). Rizomaintroducción. Valencia: Pretextos.

Derrida, J. \& Stiegler, B. (1998). Ecografías de la televisión. Buenos Aires: Eudeba.

Descartes, R. (año). Meditaciones metafísicas. Bogotá: Panamericana.

Eco, U. (1999). Obra abierta. Barcelona: Ariel.

Evangelista, L. (1996). "La poética de Alejandra Pizarnik", Atenea, n 473, Concepción, Universidad de Concepción, pp. 41-51.

Fabb, N. (Comp.) (1989). La lingüística de la escritura: debates entre lengua y literatura. Madrid: Visor.

Gallo, Marta. (1983). "Los espejos de Alejandra Pizarnik", Letras de Buenos Aires, $\mathrm{n}^{\circ}$ 9, Buenos Aires, pp. 9-20.

Goffman, E. (1975). Estigma. Paris: Minuit.

Habermas, J. (1989). "Modernidad: un proyecto incompleto". En El debate modernidad-posmodernidad. Buenos Aires: Punto Sur, pp. 131144.

Iser, W. (1987). El acto de leer. Madrid: Taurus.

Jameson, F. (2001). Teoría de la postmodernidad. Madrid: Trotta.

Le Breton, D. (2002a). Antropología del cuerpo y modernidad. Buenos Aires: Nueva Visión. . (2002b). La sociología del cuerpo. Buenos Aires: Nueva Visión.

Lyotard, F. (1987). La condición posmoderna. Madrid: Cátedra.

López, M. (2002). "Los discursos poéticos en la obra de Alejandra Pizarnik", Espéculo. Revista de Estudios Literarios, $\mathrm{n}^{\circ} 21$, Madrid, Universidad Complutense, en http://www.ucm.es/info/especulo/numero21/ pizarnik.html

Olivares, J. (2008). "Entre la ceniza y el fantasma. El sujeto desencantado en la literatura y el cine contemporáneos", Espéculo. Revista de Estudios Literarios, $\mathrm{n}^{\circ} 39$, Madrid, Universidad Complutense, en http://www.ucm.es/info/especulo/numero39/eceniza.html.

Pavis, P. (1990). Diccionario de términos teatrales. Buenos Aires: Paidós.

Piña, C. (1999). Alejandra Pizarnik. Una biografía. Buenos Aires: Ediciones Corregidor.

Pérez Stanfield, M. (1986). “El héroe en las 'tragedias complejas' de Alfonso Sastre”, Actas del IX Congreso de la Asociación Internacional de Hispanistas, vol. II, Berlín, pp. 327-336.

Pizarnik, A. (1994). Poesía completa y prosa selecta (Edición de C. Piña). Buenos Aires: Corregidor.

- (2001). Poesía completa (Edición de A. Becciú). Barcelona: Lumen. 
(2006). Prosa completa. Barcelona: Lumen.

Ricoeur, P. (2004). Finitud y culpabilidad. Madrid: Trotta.

Rodríguez Francia, A.M. (2009). "Alejandra Pizarnik y María Rosa Lojo. Cuestionamiento del lenguaje en la prosa argentina", Analecta literaria: Revista de Letras, Ideas, Artes y Ciencias, en http:// actaliteraria.blogspot.com/2009/03/pizarnik-y-lojo.html (Publicado originalmente en Revista Letras, $\mathrm{n}^{\circ} 34$ (JulioDiciembre), 1996, pp. 123-239.

Roggiano, A. (1981). "Alejandra Pizarnik: Persona y poesía”, Letras de Buenos Aires, $\mathrm{n}^{\circ}$ 2, Buenos Aires, pp. 49-58.

Sábato, E. (1951). Máquinas y engranajes. Buenos Aires: Alianza.

Schopenhauer, A. (1998). Ensayo sobre las visiones de fantasmas. Madrid: Valdemar.

Venti, P. (2003). "Las diversiones púbicas de Alejandra Pizarnik", Espéculo. Revista de Estudios Literarios, $\mathrm{n}^{\circ} 23$, Madrid, Universidad Complutense, en http://www.ucm.es/info/especulo23/numero/ pizarnik.html 
